\title{
PLACENTAS CHANGES IN GESTATIONAL HYPERTENSIVE WOMEN IN DUHOK
}

\author{
GHAZAL HUSSEIN KHALEEL, BVM\&S* \\ SAADI SALEH MOHAMMED BARWARI, BSc, MSc, PhD (Embryology)**
}

\section{Submitted 16/01/2019; accepted 24/03/2019}

\begin{abstract}
Background: Placentas impact by hypertensive disorders and contribute significantly to maternal and fetal morbidity and mortality. This study was designed to investigate the gross and histological changes in the placentas of gestational hypertensive women.

Patients and Methods: The samples of this cross sectional study were collected from Duhok Obstetrics and Gynecology Hospital, Duhok city, Kurdistan region, Iraq. Total 73 placentas were collected from 20-40 years old women with full-term singleton pregnancies, 25 placentas from normo-tensive mothers having no hypertension before as control group and 48 from gestational hypertension women as gestational hypertension group. The maternal and neonatal data were recorded. Immediately after delivery, the placenta was washed, dried, photographed then weighted and dimensions were measured. Morphological features were recorded. Central biopsies were taken for qualitative and quantitative histopathological examination which included: terminal villi, stromal fibrosis, fibrinoid necrosis, calcification, syncytial knots, hyalinization, medial coat proliferation of medium sized blood vessel, avascular villi, congestion, chorangiosisandvasculosyncytial membrane. Statistical analyses were done by using student t-test and chi- square test.
\end{abstract}

Results: In the gestational hypertension, macroscopically, there was no statistical difference. Microscopic finding revealed a significant increase in calcification, fibrinoid necrosis, stromal fibrosesand congestion; whereas vasculosyncytial membrane and avascular villi increased insignificantly and chorangiosiswas not impacted. The gross and histological qualitative results coincided with the quantitative results.

Conclusions: The placentas were significantly and adversely affected by the gestational hypertension.

Duhok Med J 2019; 13 (1):96-111.

Keywords: Placentas, Full-Term Singleton Pregnancies, Gestational Hypertension.

$\mathrm{N}$

ormal fetal growth and survival depends on the proper development and function of the placenta, which serves to maintain a maternal-fetal interface for the exchange of blood gases, nutrients and waste ${ }^{1}$.

Gestational Hypertension (GH) is one of the common complications occurred with in pregnancy and diagnosed if maternal blood pressure is more than $140 / 90 \mathrm{~mm}$ $\mathrm{Hg}$, in the $2^{\text {nd }}$ half of pregnancy (after 20 weeks of gestation) without protein urea ${ }^{1,2}$. The complications of $\mathrm{GH}$ affected the placenta in significant ways both macroscopically and microscopically and it is also commonly associated with placental insufficiency, thereby resulting in fetal growth retardation ${ }^{3}$.

* Assistant Lecturer., Department of Anatomy, biology and Histology, College of Medicine, University of Duhok, Kurdistan Region, Iraq.

** Lecturer., Department of Anatomy, biology and Histology, College of Medicine, University of Duhok, Kurdistan Region, Iraq. 


\section{PLACENTAS CHANGES IN GESTATIONAL HYPERTENSIVE WOMEN}

Excess fetal deaths about $70 \%$ in women with hypertension"GH, preeclampsia, super imposed preeclampsia and chronic hypertension" are due to large placental infarcts, small placental size and that histopathological changes related to confined placental mosaicism may be associated with inadequate placentation and hence with retro placental ischemia ${ }^{4}$.

Kambale et al in 2016 recorded gross description of placenta; Where most of the placentas were smaller than expected, although some subsets were larger than expected. Infarction, fibrinoid deposits and calcification are the most common changes. Fetal complications generally result from the characteristic placental alterations ${ }^{5}$.

There is still no local study on this subject. Thus, the present study was conducted to study the gross and histological variations of human placenta in gestational hypertensive disorders.

\section{MATERIALS AND METHODS}

This cross sectional study was approved by the Medical Ethics Committee of Duhok Directorate of General Healthy-Directorate of General Research Division.

The study was conducted in the Department of Anatomy and Histology, College of Medicine, University of Duhok, Kurdistan region, Iraq, from the $27^{\text {th }}$ of February until the $1^{\text {st }}$ of October 2018.

\section{Source and Methods of Data Collection}

The Study sample which was 73 placentas were collected from women who were between 20-40 years old, singleton pregnancies, and full-term (37-41 weeks gestational age), for the control and $\mathrm{GH}$ cases in both groups.
All the women were examined by the medical staff in Duhok Obstetrics and Gynecology Hospital. The main maternity hospital in Duhok city. The placentas were collected in the operative and delivery rooms.

Out of 73 placentas, 25 were normal placentas from normotensive women (control group), the 48 placentas were collected from women with gestational hypertension only without proteinurea $(\mathrm{GH}$ group).

All patients were delivered by Caesarean section (CS), emergency and elective type of CS, and all infants were live born and without any evidence of congenital infection or malformation.

\section{Data of the Women and Neonate}

Full history was taken from the women before delivery which included; Obstetrical and medical history, history of chronic diseases, medicine intake, history of smoking and any complication in previous pregnancies.

Then all demographic and clinical data were extracted from maternal and neonatal medical records at hospital which includes: name and age of patient, address, telephone, parity, gravid, gestational age in weeks. A general examination was done for all the women included the following: hemoglobin level, general urine examination (urine for albumin and pus cells examination), blood pressure (it was measured at least two times, six hours apart), platelet count, random or fasting blood sugar, blood urea and serum creatinine. Ultrasound examination was done for the assessment of gestational age and fetal well-being. Following delivery, the complete records of data concerned the newborn baby have included; sex, weight 
which was measured by electric balance (digital baby weight, electric co., LTD, Japan) and congenital anomaly.

\section{Exclusion Criteria}

The placentas of following complications were excluded: preterm pregnancies, placental tumors, hypothyroidism, anemia, chronic hypertension, preeclampsia, any cases complicated by chronic disease like diabetes, renal disease, also, smoking and/or alcohol intake pregnant women. In addition, women with antepartum hemorrhage (abruption placentae, vasa previa and placenta previa) were excluded from the study.

\section{Placentas Examination}

\section{a. Macroscopic examination}

The placenta with cord and membranes were collected immediately after delivery. Any abnormality of the placenta was noted. In all the cases, the amnion and chorion were trimmed from the placenta. The umbilical cord was cut at a distance of 3 centimeters from the site of insertion by sharp scissors. Placentas were washed in slow running tap water to remove blood clots. Excess water was removed by clean gauze. The maternal and fetal surfaces were inspected for the presence of infarction, calcification and fibrinoid. The placentas then photographed by camera (Canon EOS 550D, Japan), then weighted by using (digital baby weight, Tokyo, electric co. LTD, Japan), after that the shape of placentas (discoid, oval, irregular) were recorded, then the placentas were kept on a flat tray, the maximum diameter of was measured by taking two dimensions from longest and shortest area by using metal ruler and then the mean was taken, the number of cotyledons was calculated, the position of insertion of umbilical cord (central, eccentric, and Marginal) On the fetal surface of placenta was determined.

\section{b. Microscopic examination}

For each placenta, two central biopsies were taken randomly with full thickness for qualitative and quantitative histological and histopathological examinations and fixed in $10 \%$ neutral buffer formalin. After 24 hours of fixation, the trimmed 3 millimeters thick slices were transferred into plastic tissue cassettes, they were labeled and put into tissue container of automated processor(LEICA ASP 300S, Germany).

The steps of automated processing were according to Bancroft and Stevens ${ }^{6}$ as follows: Fixation (extra fixation), Dehydration, Clearing, Infiltration, Embedding, Blocking, Cutting and Staining .The prepared slides were stained with Harris Hematoxylin and Eosin.

\section{c.Histological examination of the section} Stained sections were examined by the light microscope (Nicon Y-THS, Japan) at magnification X40, X100, and X400. Both qualitative and quantitative changes were measured: Qualitative and quantitative (From each section, 10 fields were taken ${ }^{7}$ examinations focused on all histological components, including maternal and fetal parts (chorionic plate, chorionic villi and their stroma, fetal blood vessels, number of terminal villi, syncytial knots, area of hyalinization, area of calcification, area of fibrinoid, area of stromal fibrosis, medial coat proliferation of medium sized of blood vessels (MCP), congestion, immature villi and any other changes of tissues). All the above mentioned structures were taken as standard control for comparison of the corresponding ones 


\section{PLACENTAS CHANGES IN GESTATIONAL HYPERTENSIVE WOMEN}

of the hypertensive cases, which also has been thoroughly examined.

The recorded data were analyzed by Statistical Package for Social Science (SPSS) version 20 and analyzed. Statistical analyses were done by using student t-test and chi- square test. The data were presented as "means \pm standard deviations (SD)". The $P$-value $\leq 0.05$ was considered as statistically significant.

\section{RESULTS}

\section{Maternal and Neonatal Demographic Characteristics}

A total of 73 placentas were studied. Out of which 25 (34\%) placentas were from normotensive term mothers (BP < 140/80) which formed the control group and 48 (66\%) placentas were from mothers with hypertension (BP > 140/80) who formed gestational hypertension. All the mothers in the control group and the $\mathrm{GH}$ group satisfied the selection criteria.

Out of the 25 controls $11(44 \%)$ were primigravida and $14 \quad(56 \%)$ were multigravida. Out of 48 gestational hypertension cases $19 \quad(40 \%)$ were primigravida and 29 (60\%) were multigravida. This shows that in the present study GH was more common in multigravida.

The gender of neonate was as following: in control (17 males, 8 females), in GH group (25 males, 23 females). The data of $\mathrm{GH}$ group revealed collectively no statistical difference.

Demographic characteristics of the control group showed that maternal mean age was (28.400 \pm 4.330 years), the gestational age was $(38.68 \pm 0.900$ weeks), parity was $(1.960 \pm 1.098)$ and a neonate weight was $(3222 \pm 425.3$ grams). Demographic characteristics of $\mathrm{GH}$ group revealed insignificant increase in maternal age $(30.708 \pm 5.841$ years) and parity (2.395 \pm 1.954$)$. While, the gestational period $(38.145 \pm 1.091$ weeks $)$ with $p=0.039$ decreased significantly and neonate weight (3067 \pm 667.4grams) decreased insignificantly as in Table 1.

\begin{tabular}{|c|c|c|c|}
\hline Parameters & $\begin{array}{c}\text { Control } \\
\text { group } \\
\text { (Mean } \pm \\
\text { SD) }\end{array}$ & $\begin{array}{c}\text { GH group } \\
\text { ( Mean } \pm \\
\text { SD) }\end{array}$ & $\begin{array}{c}P \text { - } \\
\text { value }\end{array}$ \\
\hline Age (years) & $\begin{array}{c}28.400 \pm \\
4.330\end{array}$ & $\begin{array}{c}30.708 \pm \\
5.841\end{array}$ & 0.086 \\
\hline $\begin{array}{l}\text { Neonatal } \\
\text { weight } \\
\text { (grams) }\end{array}$ & $\begin{array}{l}3222 \pm \\
425.3\end{array}$ & $\begin{array}{l}3067 \pm \\
667.4\end{array}$ & 0.296 \\
\hline $\begin{array}{c}\text { Gestational } \\
\text { period } \\
\text { (weeks) }\end{array}$ & $\begin{array}{c}38.68 \pm \\
0.900\end{array}$ & $\begin{array}{c}38.145 \pm \\
1.091\end{array}$ & 0.039 \\
\hline Parity & $\begin{array}{c}1.960 \pm \\
1.098\end{array}$ & $\begin{array}{c}2.395 \pm \\
1.954\end{array}$ & 0.306 \\
\hline $\begin{array}{c}\text { No. of } \\
\text { cotyledons }\end{array}$ & $\begin{array}{c}17.640 \pm \\
4.536\end{array}$ & $\begin{array}{c}16.72 \pm \\
4.551\end{array}$ & 0.420 \\
\hline $\begin{array}{c}\text { Placental } \\
\text { weight } \\
\text { (grams) }\end{array}$ & $\begin{array}{l}505.4 \pm \\
87.962\end{array}$ & $484 \pm 114.3$ & 0.416 \\
\hline $\begin{array}{l}\text { Placental } \\
\text { diameter } \\
(\mathrm{cm})\end{array}$ & $\begin{array}{c}19.200 \pm \\
2.005\end{array}$ & $\begin{array}{c}18.56 \pm \\
2.233\end{array}$ & 0.235 \\
\hline $\begin{array}{l}\text { Placental } \\
\text { thickness } \\
\text { (cm) }\end{array}$ & $\begin{array}{c}2.084 \pm \\
0.246\end{array}$ & $\begin{array}{c}2.137 \pm \\
0.447\end{array}$ & 0.512 \\
\hline $\begin{array}{l}\text { Feto- } \\
\text { placental } \\
\text { ratio }\end{array}$ & $\begin{array}{c}6.463 \pm \\
0.799\end{array}$ & $\begin{array}{c}6.538 \pm \\
1.326\end{array}$ & 0.796 \\
\hline
\end{tabular}

\section{Macroscopic Observations of Placentas}

The control group revealed that the placental diameter was $(19.200 \pm 2.005$ $\mathrm{cm})$, placental weight was $(505.4 \pm 87.962$ grams), the number of cotyledons was (17.64 \pm 4.536$)$, the central thickness was $(2.084 \pm 0.246 \mathrm{~cm})$ and the feto-placental ratio was $(6.463 \pm 0.799)$ as in Table 1. 
The placental shape was normal oval in 6 cases, discoid in 13 cases, and irregular in 6 cases as in Figure 1 and Table 2. Triangular, quadrant and leaf shape placentas were recorded as an irregular shape.

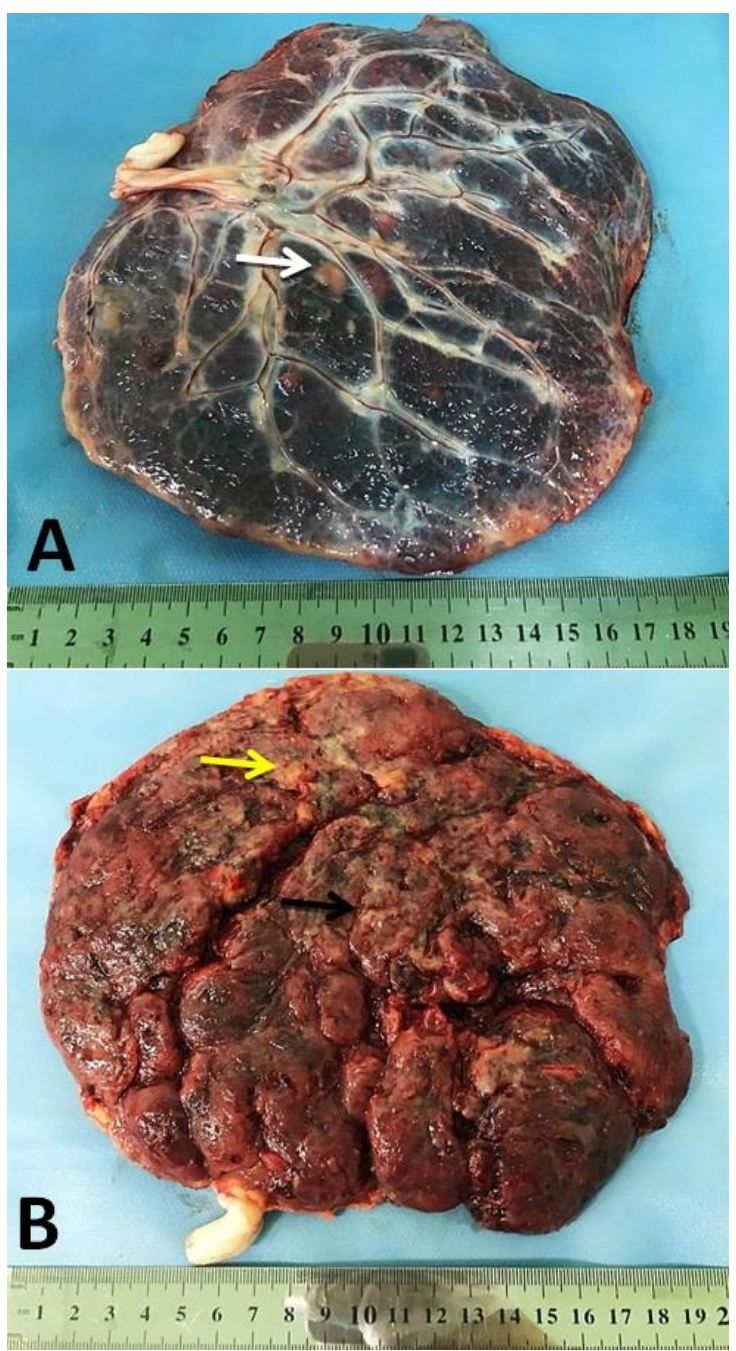

Figure 1: Photographs of Normal Placenta Showing (A) Fetal Surface, (B) Maternal Surface, Notice of the Irregular Shape of Placenta, Eccentric Insertion of Umbilical Cord, Fibrinoid Deposition(White Arrows), Infarction (Yellow Arrow) and Calcification (Black Arrow).

The umbilical cord insertion was central in 6 cases and eccentric in 19 cases as in Figure 1 and Table 2.
Table 2: Various Shapes of Placentas and Type of Umbilical Cord Insertion in the Both Control and GH Groups.

\begin{tabular}{|c|c|c|c|c|}
\hline Groups & $\begin{array}{c}\text { Oval } \\
\text { No }(\%)\end{array}$ & $\begin{array}{l}\text { Discoid } \\
\text { No }(\%)\end{array}$ & $\begin{array}{c}\text { Irregular } \\
\text { No }(\%)\end{array}$ & Total \\
\hline Control & $6(24)$ & $13(52)$ & $6(24)$ & 25 \\
\hline $\mathbf{G H} \mathbf{H}^{1}$ & $19(40)$ & $13(27)$ & $16(33)$ & 48 \\
\hline Groups & $\begin{array}{l}\text { Central } \\
\text { No }(\%)\end{array}$ & $\begin{array}{c}\text { Eccent } \\
\text { ric } \\
\text { No }(\%)\end{array}$ & $\begin{array}{c}\text { Marginal } \\
\text { No }(\%)\end{array}$ & Total \\
\hline Control & $6(24)$ & 19(76) & $\mathbf{0}(\mathbf{0})$ & 25 \\
\hline $\mathbf{G H}^{2}$ & $6(12.5)$ & $\begin{array}{c}38(79.2 \\
)\end{array}$ & $4(8.3)$ & 48 \\
\hline
\end{tabular}

$P$-value $=0.105$ and ${ }^{2} P$-value $=0.180$

Macroscopic examination of the placental surfaces revealed fibrinoid deposits in 14 cases, calcification in 21cases, and infarctions in 13 cases as in Figure 1 and Table 3.

\begin{tabular}{cccc}
\hline \multicolumn{4}{c}{ Table 3: Placental Gross Lesion on the Fetal and } \\
Maternal Surfaces. & Control & GH & $P$ - \\
value \\
Parameters & N $(\%)$ & N $(\%)$ & \\
$\begin{array}{c}\text { Calcification } \\
\text { (Maternal }\end{array}$ & $21(84)$ & $43(89.5)$ & 0.482 \\
$\begin{array}{c}\text { Surface) } \\
\text { Infarction } \\
\text { (Maternal } \\
\text { Surface) }\end{array}$ & $13(52)$ & $30(62.5)$ & 0.387 \\
$\begin{array}{c}\text { Fibrinoid } \\
\text { (Fetal surface) }\end{array}$ & $14(56)$ & $33(69)$ & 0.280 \\
\hline
\end{tabular}

The GH group revealed that the placental diameter $(18.56 \pm 2.233 \mathrm{~cm})$, placental weight $(484.0 \pm 114.3 \mathrm{gms})$ and the number of cotyledons $(16.72 \pm 4.551)$ decreased insignificantly while the placental thickness $(2.137 \pm 0.447 \mathrm{~cm})$ and fetoplacental ratio $(6.538 \pm 1.326)$ increased insignificantly as in Table 1.

Placental shapes were oval in 19 cases, discoid in 13 cases, and irregular in 16 cases, and no statistical significance was detected as in Figure 2 and Table 2. 
The umbilical cord insertion revealed central in 6 cases, eccentric in 38 cases and marginal in 4 cases; no statistical significance was detected as in Figure 2 and Table 2. Macroscopic examination of the placental surfaces revealed increases in fibrinoid deposits in 33 cases, infarction in 30 cases and calcification in 43 cases; no statistical significance was detected as in Figure 2 and Table 3.

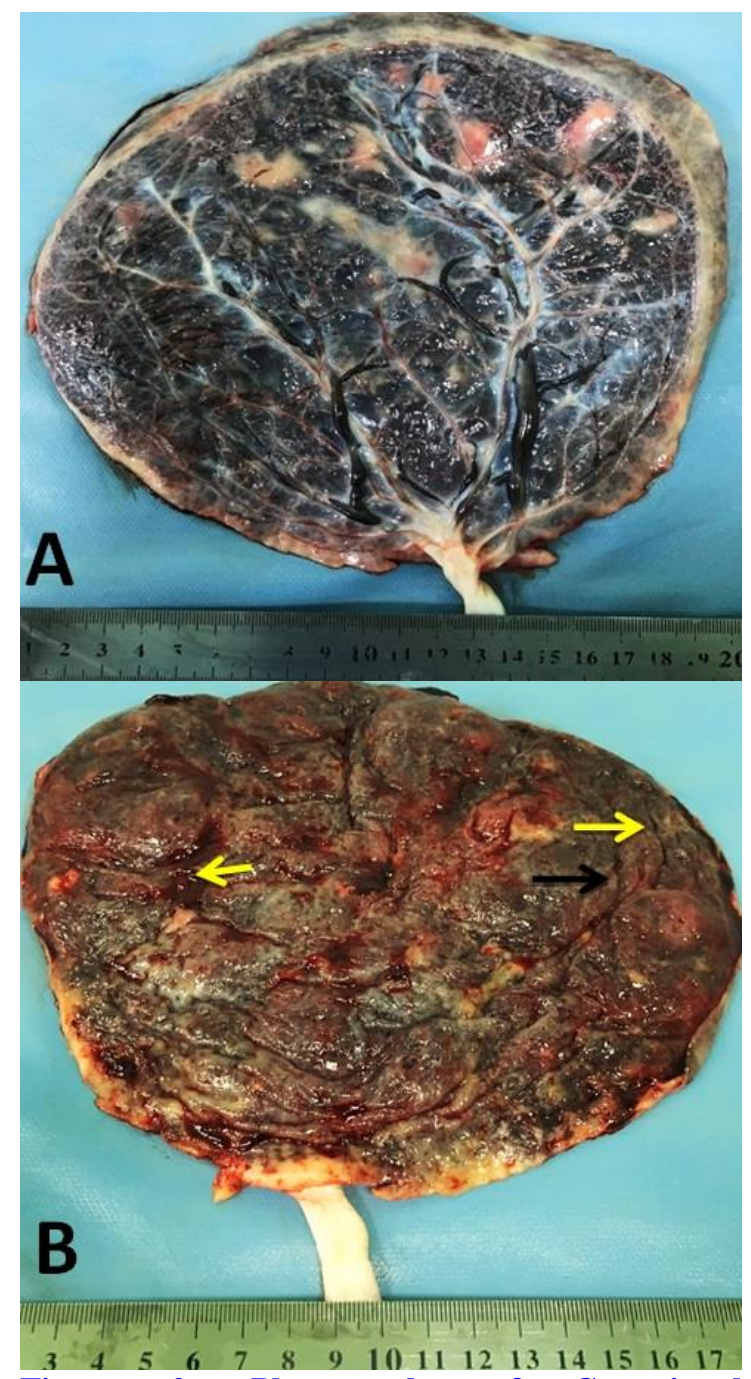
Figure 2: Photographs of Gestational Hypertension Placenta Showing (A) Fetal Surface, (B) Maternal Surface, Notice of the Oval Shape of Placenta, Marginal Insertion of Umbilical Cord, Fibrinoid Deposition(White Arrows), Infarction (Yellow Arrow), and Calcification (Black Arrows).
Histological Findings of Placenta in Cases and Control Groups

\section{Qualitative Observation}

Microscopic examination of the placenta in control group appeared terminal villi as small, round or oval structures with core of connective tissues surrounded by continuous syncytiotrophoblast layer each terminal villous was rich with fetal capillaries and separated from each other by intervillous spaces filled with maternal blood.

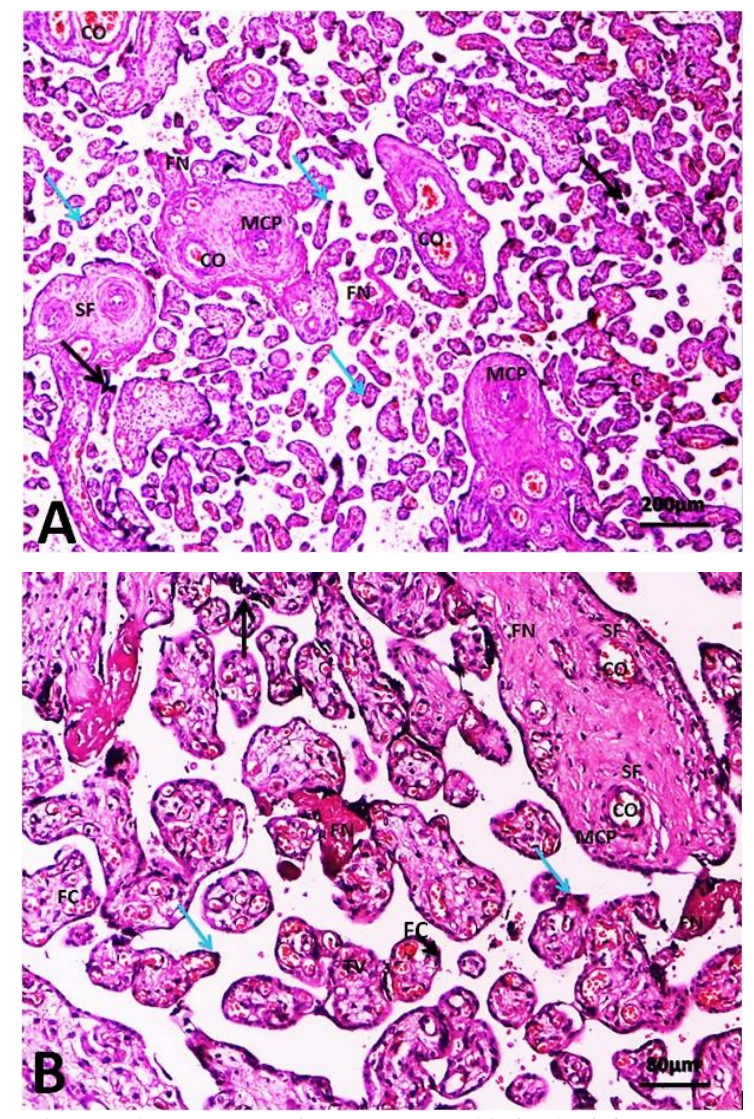

Figure 3: Photomicrographs (A\&B) Of Normal Placenta. Showing Terminal Villi (TV) with Core of Connective Tissues(C) were Overcrowded, Rich with Fetal Capillaries (FC) and Separated From each other by Intervillous Spaces Filled with Maternal Blood. Notice Syncytial Knots (Blue Arrows), Calcification (Black Arrows) Stromal Fibrosis (SF), Congestion (CO), and Fibrinoid Necrosis (FN) ( $A=X 40, H \& A ; B=X 100, H \& E)$.

The stem villous was distinguished from the peripheral terminal villous by their large size and presence of one or several 
arteries and veins or arterioles and venules with clearly visible muscular walls.Syncytial knots present with terminal villi, between villi and sometimes found free in the intervillous spaces. Fibrinoid may replace the trophoblastic cover of villi, and it is called perivillous fibrinoid. In other villi, it replaces the stroma beneath the intact trophoblastic surface (intravillous fibrinoid). Some chorangiosis, congestion, and few placentas with hyalinization and calcification were seen. Vasculo-syncytial membrane was seen in villi as attenuated areas of syncytiotrophoblast, which over lie and appeared to fuse with the wall of adjacent dilated fetal capillary as in Figure 3.

The specific histological changes found in gestational hypertension placentas were as follows: terminal villi decreased in number and diameter. There was an increase incidence in fibrinoid necrosis in placenta. The nuclei of trophoblasts showed some changes with a tendency toward the formation of clusters especially when the syncytial layer progresses buds (knots) protruding in to the intervillous spaces and (decrease syncytial knots formation). There was a decreased in chorangiosis, congestion and hyalinization. Stromal fibrosis was present extensively; Calcification occurred in most cases of gestational hypertension in the core of villi and in the decidua basalis. There were degeneration and fibrosis in endothelial wall of stem villi blood vessels. There was an increased incidence of fibrinoid necrosis in perivillous and intervillous area. Avascular villi were increased in these casesas in Figure 4.

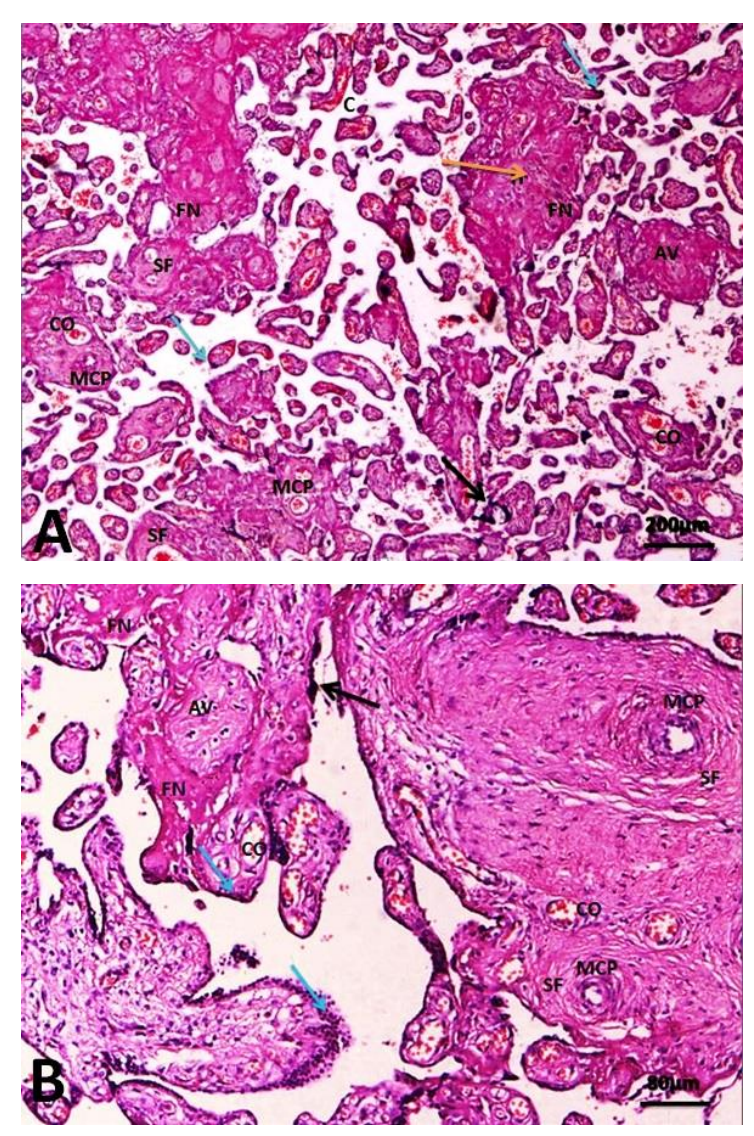

Figure 4: Photomicrographs (A\&B) of Gestational Hypertension Placenta. Showing Terminal Villi with Core of Connective Tissues, Fetal Capillaries and Separated From each Other by Intervillous Spaces Filled with Maternal Blood. Notice Syncytial Knots (Blue Arrows), Calcification (Black Arrows) Stromal Fibrosis (SF), Congestion (CO), MCP (MCP), Chorangiosis (C), Hyalinization (H), Avascular Villi(AV) and Fibrinoid Necrosis (FN) (A=X40, H\&E; B=X100, H\&E).

\section{Quantitative Observations}

The microscopic study of placenta in control group showed that the terminal villi were $(8.952 \pm 3.091)$, syncytial knots formation was $(7.924 \pm 2.082)$, stromal fibrosis was $(6.424 \pm 2.910)$, fibrinoid necrosis was $(6.424 \pm 2.910)$, hyalinization was $\quad(0.080 \pm 0.147), \quad \mathrm{MCP}$ was (3.604 \pm 1.648$)$,vasculosyncytial membrane was $(10.388 \pm 4.451)$ and calcification was $(0.556 \pm 0.351)$ as in Table 4. The control group showed congestion in 14 cases, chorangiosis in 8 cases and avascular villi in 9 cases as in Table 5 . 


\section{PLACENTAS CHANGES IN GESTATIONAL HYPERTENSIVE WOMEN}

\begin{tabular}{|c|c|c|c|}
\hline Parameters & $\begin{array}{c}\text { Control } \\
\text { (Mean士 } \\
\text { SD) }\end{array}$ & $\begin{array}{c}\text { GH } \\
\text { (Mean } \\
\pm \\
\text { SD) }\end{array}$ & $P$ - value \\
\hline Terminal villi & $\begin{array}{c}8.952 \pm \\
3.091\end{array}$ & $\begin{array}{c}8.799 \pm \\
1.809\end{array}$ & 0.780 \\
\hline $\begin{array}{c}\text { Syncytial } \\
\text { knots }\end{array}$ & $\begin{array}{c}7.924 \pm \\
2.082\end{array}$ & $\begin{array}{c}7.567 \pm \\
1.467\end{array}$ & 0.397 \\
\hline $\begin{array}{c}\text { Fibrinoid } \\
\text { necrosis }\end{array}$ & $\begin{array}{c}6.424 \pm \\
2.910\end{array}$ & $\begin{array}{c}8.227 \pm \\
2.578\end{array}$ & 0.0004 \\
\hline Hyalinization & $\begin{array}{c}0.080 \pm \\
0.147\end{array}$ & $\begin{array}{c}0.098 \pm \\
0.177\end{array}$ & 0.666 \\
\hline Calcification & $\begin{array}{c}0.556 \pm \\
0.351\end{array}$ & $\begin{array}{c}0.789 \pm \\
0.384\end{array}$ & 0.013 \\
\hline $\begin{array}{l}\text { Stromal } \\
\text { fibrosis }\end{array}$ & $\begin{array}{c}6.424 \pm 2 . \\
910\end{array}$ & $\begin{array}{c}8.881 \pm \\
3.125\end{array}$ & 0.002 \\
\hline $\begin{array}{l}\text { Vasculo- } \\
\text { syncytial } \\
\text { membrane }\end{array}$ & $\begin{array}{c}10.388 \pm \\
4.451\end{array}$ & $\begin{array}{c}11.892 \pm \\
4.023\end{array}$ & 0.148 \\
\hline $\begin{array}{c}\text { Medial coat } \\
\text { proliferation } \\
\text { of medium } \\
\text { sized blood } \\
\text { vessels }\end{array}$ & $\begin{array}{c}3.604 \pm \\
1.648\end{array}$ & $\begin{array}{c}3.571 \pm \\
1.354\end{array}$ & 0.927 \\
\hline
\end{tabular}

Histological examination of placenta of the GH group were revealed an increase with very highly statistical significant in fibrinoid necrosis $(8.227 \pm 2.578)$ with $P=0.0004$ and highly statistical significant increase in stromal fibrosis $(8.881 \pm 3.125)$ with $P=0.002$, also showed significant increase in calcification $(0.789 \pm 0.384)$ with $=0.013$ and insignificant increase in hyalinization $(0.098 \pm 0.177)$. However, the syncytial knots $(7.567 \pm 1.467)$, terminal villi $(8.799 \pm 1.809)$ and MCP $(3.571 \pm 1.354) \quad$ were decreased insignificantly.

The vasculosyncytial membrane (11.892 \pm 4.023$)$ increased insignificantly as in Table 4. Congestion in 38 cases increased and showed statistical significance with $P=0.038$, chorangiosis in 15 cases decreased insignificantly and avascular villi in 26 cases increased insignificantly as in Table5.

\begin{tabular}{|c|c|c|c|}
\hline \multicolumn{4}{|c|}{$\begin{array}{c}\text { Table 5: Distribution of Chorangiosis, } \\
\text { Congestion, and Avascular Villi in Placenta of } \\
\text { Five Groups. }\end{array}$} \\
\hline \multirow[b]{2}{*}{ Parameters } & \multicolumn{2}{|c|}{ Groups } & \multirow{2}{*}{$\begin{array}{c}P \text { - } \\
\text { value }\end{array}$} \\
\hline & $\begin{array}{c}\text { Control } \\
\text { No }(\%)\end{array}$ & $\begin{array}{l}\text { GH } \\
\text { No }(\%)\end{array}$ & \\
\hline Chorangiosis & $8(32)$ & $15(31.2)$ & 0.948 \\
\hline Congestion & $14(56$ & $38(79.1)$ & 0.038 \\
\hline Avascular villi & $9(36)$ & $26(54.1)$ & 0.140 \\
\hline
\end{tabular}

\section{DISCUSSION}

The fetus, placenta and mother form a composite triad of dynamic equilibrium, and dysfunction of any one of them can affect the other ${ }^{8}$. Placenta separates the maternal and fetal circulation, with which it is in contact through different surfaces, i.e. the syncytiotrophoblast exposes the placenta to the maternal circulation. Because of this unique position, the placenta is exposed to the regulatory influence of hormones, cytokines, growth factors, and substrates present in both circulations and hence may be affected by changes in any of these. In turn it can produce molecules that will affect the mother and fetus independently'.

Placenta, being a fetal organ shares the same stress and strain, to which the fetus is exposed. Thus any disease process affecting the mother or the fetus also has a great impact on placenta. Normally the placental morphology varies considerably during its short life span. Alterations in placenta as part of "Ageing" phenomenon are probably a part of the maturation process and go hand in hand with 
continued growth of placenta. Placenta grows till 37 weeks; immature villi are seen even till term ${ }^{10}$.

Hence in the study on placenta, Fox has stressed the importance of analyzing the placental pathology quantitatively. These changes are considered pathological when the extent of involvement is greater than normal $^{11}$.

\section{Maternal and Neonatal}

The results of the present study indicated that multigravida patients were more frequent than primigravida in gestational hypertension cases. That mean gestational hypertension may be a disease of multigravida. In contrast, other studies found that hypertension is a disease of primigravida $^{12,13,14,15}$.

With regard to the gender of the neonate, the current study found no statistical differences in gestational hypertension group when compared to control group. This is indicated that the sample of the present study was randomly selected for investigated groups and no association between placentas and gender of neonates were observed.

In hypertension patients, it was found that maternal age in $\mathrm{GH}$ group insignificantly increased. In contrast, other study found that there was no statistical difference between $\mathrm{GH}$ and control groups ${ }^{16}$. The result of present study indicated that women in $\mathrm{GH}$ group were older than women in the control group.

In the present study, the birth weight of neonates was significantly low in the $\mathrm{GH}$ group. Rosana et al, Shevade et al, Majumdar et al and Baloch et al observed similar finding in the birth weight of neonates ${ }^{17,18,19.20}$. Gestational age at delivery of GH groups was less than that of the control group. This result goes with that of other studies ${ }^{21,22,23,24}$.

\section{Macroscopic Observations}

The changes in placental weight, diameter and thicknesses were observed in the present study. Study groups showed placental weight, diameter and thicknesses decreased insignificantly in GH. Similar finding have been reported by many researchers $25,26,27,28,29$. Shalini reported that placentas from $\mathrm{GH}$ groups were smaller than that of normal group which indicated that an underlying pathological process was interfering with the normal growth of placenta ${ }^{10}$.

In the present study, the numbers of cotyledons were ranging from 16-20. There was no statistical significant difference regarding this in control group and GH group. The study conducted by Karmakar et al. Also did not find a difference between test and control $\operatorname{group}^{29}$.

The mean feto-placental ratio insignificantly increased in the GH group as compared to control group in the present study. This is not concordance with other studies. Al-Mamori in his study has attributed the relatively low fetoplacental ratio to decreased surface area for diffusion or increased diffusion distance leading to fetal compromise ${ }^{30}$. Kurdukar et al suggested that there is compensatory hypertrophy of placental mass in response to chronic hypoxia in hypertension cases. This hypertrophy along with low birth weight of the fetus contributes to low feto-placental ratio in hypertension cases ${ }^{31}$.

In the present study, the various shapes of placentas are found in both groups. 


\section{PLACENTAS CHANGES IN GESTATIONAL HYPERTENSIVE WOMEN}

In GH groups, the oval and irregular shapes of placentas were more as compared to discoid shape. Where as in the control group, the circular shape was the majority. These observations are comparable with other studies ${ }^{32,15}$.

The incidence of marginal and eccentric insertion of the umbilical cord in the $\mathrm{GH}$ group was more than that of the control group. This is an identical with the findings of Fox, Majumdar et al, Agarwal et al and shalini ${ }^{33}, 19,34,10$. Marginal insertion of the cordresults in an altered of the distribution of fetal blood in the placenta as a result of different modes of arrangement of intracotyledonary vessels of placentas of complicated pregnancy. This vascular arrangement may be hampering equal distribution of blood flow in the placenta, increasing the risk to the mother and fetus ${ }^{10}$. Calcification observed in both control and GH placentas in the present study. Calcification is regarded as an evidence of placental senescence or degeneration as it is increased at term. It is not associated with adverse fetal outcome. In present study no statistical significance was observed between the two groups which are comparable with ${ }^{12,15}$.

The infarction was insignificantly increased in the GH group. Kurdukar et al have reported that thrombotic occlusion of maternal uteroplacental vessel is responsible for infarction ${ }^{31}$. Fox are of the opinion that extensive infarcts affects fetal outcome $^{33}$. Jain et al have shown that extensive infarcts are associated with higher incidence of fetal hypoxia and intrauterine death ${ }^{12}$. The incidence of placental infarction was related to the severity of hypertension in these cases and not to any other maternal factor ${ }^{35}$.
The percentage of fibrinoid deposition in $\mathrm{GH}$ cases was more than control cases. It caused due to subchorionic fibrin deposits which may be seen in all term placentas and are not of clinical significance, as stated by Dhawle et $a l^{35}$.

\section{Microscopic Observations}

In the study group, the histology revealed various structural changes such as number of syncytial knots, areas of fibrinoid necrosis, areas of MCP, areas of calcification, areas of hyalinization, areas of stromal fibrosis, vasculosyncycial membrane, terminal villi, chorangiosis, and congestion.

The present study showed insignificant increase in the mean number of the terminal villi between the GH group and the control group.

Syncytial knots are consistently increasing with increased gestational age can be used to evaluate villous maturity. In the present study, the syncytial knots formation "and gestational age" in GH groups weredecreased. Similar findings observed by Bandekar and $\mathrm{Kale}^{24}$. Kristinal et al., reported that increased number of syncytial knots in placentas of mothers with GH lead to fetal growth restriction induced by hypoxia ${ }^{36}$. In this study, the syncytial knots formation were insignificantly decreased in $\mathrm{GH}$ group.

The fibrinoid necroses were increased very high significantly in GH group when compared to normal term pregnancy. This result agrees the finding of other reaserches ${ }^{21,37,24}$. Fibrinoid necrosis has been considered as a hallmark of an immunological reaction within the trophoblastic tissue. In an earlier report villous fibrinoid necrosis was considered to evolve from a degenerative change in 
villous cytotrophoblast, but still it is considered to be an enigma as its pathogenesis and significance is not known $^{21,37}$.

The current study showed that the mean number of hyalinization area was increased in GH cases. Similarly, the histopathological studies done by Ahmed et al., Ranga et al., and Bandekar and Kale showed significant increase in hyalinization area of hypertensive cases when compared to control cases $8,16,24$.

The mean number of calcified areas seen microscopy were more in GH groups than in normal placenta which corresponds with other studies ${ }^{13}$. Calcification is regarded as an evidence of placental senescence or degeneration as it is increased at term ${ }^{11}$. It is not associated with adverse fetal outcome. Calcification area in this study was significantly increased in GH group.

The stromal fibrosis increased high significantly in GH which corresponds with the study of other researchers found a significant increase in the stromal fibrosis $^{21,} 37,24$. Factors those are responsible for the formation of stromal fibrosis which includes a normal aging process and a reduced uteroplacental blood flow.

Vasculo-syncytial membranes are focally differentiated areas of syncytiotrophoblast which are specifically concerned with materno-fetal transfer. The Vasculosyncytial membranes were increased insignificantly in this study which were not comparable with other studies which showed a reduction in vasculo-syncytial membrane counts ${ }^{37}$.

With regard to MCPs, there were insignificant changes in the placenta of $\mathrm{GH}$ cases. Similarly, other researchers found a significant increase in medial coat proliferation of medium-sized blood vessels $^{8,19,21}$.

In the current study, the congestion and chorangioses were insignificantly increased in GH group when compared with the control group. The numbers of avascular villi were more in $\mathrm{GH}$ groups than in normal placenta. Mehendale et al. also observed significant avascular villi in hypertension cases ${ }^{38}$. The avascular villi in hypertension placentas are the result of senescent or regressive changes in villi due to ischemia and can also be seen in prolonged pregnancies ${ }^{39}$.

There was a significant increase in syncytial knot formation in placental villi which indicates the disturbance in the hormonal factors, and may probably lead to change blood flow. According to Robertson et al, the cause of reduction in blood flow is due to vasculopathies of spiral arteries, which in turn causes reduction in the weight of placenta ${ }^{39}$. Reduced maternal utero-placental blood flow indirectly leads to constriction of fetal stem arteries. The hypertensive women will have a lower mean gestation, so the proportion of fetal capillaries will be lower. The capillaries become larger as the gestation proceeds. This relative increase in fetal capillary volume with decrease in proportion of connective tissue will lead to smaller parenchymal volume leading to decrease in placental weight. Microscopic findings of medial coat proliferation of medium sized arteries, localized fibrinoid necrosis, and hyalinization depict the mosaicism of placenta and probably the aftereffects of hypertension. Again the mosaicism of the placenta probably leads 


\section{PLACENTAS CHANGES IN GESTATIONAL HYPERTENSIVE WOMEN}

to placental insufficiency and ultimately to fetal growth retardation.

\section{CONFLICT OF INTEREST}

Further studies may be required in different settings with larger sample size and longer period. We have no conflicts of interest to disclose.

\section{REFERENCES}

1. Mustafa R, Ahmed S, Gupta A $\&$ Venuto RC. A comprehensive review of hypertension in pregnancy. $\mathrm{J}$ Pregnancy.2012; 2:1170-20.

2. Gupta D, Khan S, Noor N, \&Bhargava M. Study of pregnancy induced hypertension in relation to placental and fetal birth weight. Int J Reprod Contracept Obstet Gynecol. 2018; 7:1149-53.

3. Dicke JM. Placenta: chronicle of intrauterine growth restriction. F1000 Med Rep; 2010; 2: 69.

4. Park K. Textbook of Preventive and Social Medicine, 20th edition, Banarsidas Bhanot Publishers, Jabalpur; 2009; 482.

5. Kambale $\mathrm{T}$, Iqbal $\mathrm{B}$, Ramraje $\mathrm{S}$, Swaimul K\& Salve S. Placental morphology and fetal implications in pregnancies complicated by pregnancy-induced hypertension. Med J DY Patil Univ. 2016; 9:341-7.

6. Bancroft JD \& Stevens A. Theory and practice of histological techniques .Churchill

Levingstone,Edinburgh.1987; 482-502

7. Günyeli I, Erdemoğlu E, Ceylaner S, Zergeroğlu $\mathrm{S}$ \&Mungan $\mathrm{T}$. Histopathological analysis of the placental lesions in pregnancies complicated with IUGR and stillbirths in comparison with noncomplicated pregnancies. J Turk Ger Gynecol Assoc.2011; 12(2):75-9.

8. Ahmed \&Daver RG. Study of placental changes in pregnancy induced hypertension. Int J Reprod Contracept Obstet Gynecol.2013; 2(4): 524-527.

9. Khabat A. Ali, Lana S. Salih \&Zrar S. Almarzany the role of leptin and insulin hormones in the pregnant women serum infected of diabetic mellitus and its histological structure effects on the American Journal of Hypertension, Ltd. and umbilical cord in Erbil city Raf.J.Sci.2012; 23(3): 38 49.

10. Shalini J. Histopathological Study of Placenta in Pregnancy Induced Hypertension and its Comparison with That of Normal Pregnancies. M.V.J. Medical College \& Research Hospital, Hoskote, Bangalore. india; 2014; 560.

11. Fox H. Pathology of placenta. 2nd ed. Philadelphia: W.B. Saunders Co.Ltd.1997.

12. Jain K, Kavi V, Raghuveer CV \&Sinha R. Placental pathology in pregnancy induced hypertension with or without intrauterine growth retardation. Indian J Pathol Microbiol. 2007; 50 (3): 553557.

13. Manjunatha HK, Kishanprasad HL, Ramaswamy AS, Aravinda P, Muddegowda PH, Lingegowda JB \&etal . Study of histomorphological changes in placenta in pregnancy induced hypertension. Int J Cur Sci Res. 2012; 2(1):255-258.

14. Vijayalakshmi B, \&Kittali S. "Morphological Changes of Placenta in Cases of Pre-eclampsia and Perinatal 
Outcome." Int J Sci Stud. 2015; 3: 137142.

15. Goswami PR \& Shah SN. Placenta in Normal and Pregnancy Induced Hypertension in Relation to its Clinical Significance: A Gross Study. Int J Sci Stud. 2016; 4(7):58-61.

16. Ranga SS, Thangam AT \& Mallika V. Morphological and Histological Variations of Human Placenta in Hypertensive Disorders of Pregnancy. Int J Anat Res. 2017; 5(1):3591-3598.

17. Rosana RM, Daniel B, Camila L C, Marina CP, Flávia A O, Luís C P \& etal . Castro Placental morphometrical and histopathology changes in the different clinical presentations of Hypertensive Syndromes in Pregnancy. Arch Gynecolobstr. 2008; 277(1):201206.

18. Shevade S, Arole V, Bharambe V, Paranjape V. Morphology and Fetal Outcome in Preeclampsia And Normotensive Pregnancies. JDMS.2015; 14(4).

19. Majumdar S, Dasguptha H, Bhattacharya K \&Bhattacharya A. A study of placenta in normal and hypertensive pregnancies. J Anat Soc India. 2005; 54:34-8.

20. Baloch AH, Memon SF \& Ansari AK. Comparison of placentae from hypertension associated pregnancies and normal pregnancies. JLUMHS.2012; 11(1):3- 6

21. Narasimha A \&Vasudeva D S. Spectrum of changes in placenta in toxemia of pregnancy. Indian J Pathol Microbiol. 2011; 54 (1): 15-20.

22. Akhlaq M, Nagi AH \&Yousaf AW. Placental morphology in pre-eclampsia and eclampsia and the likely role of
NK cells. Indian J Pathol Microbiol. 2012; 55:17-21.

23. Sreechithra K, Usha P, Jayalakshmy $P$ S. Placental Pathology in Pregnancy Induced Hypertension. J Evo Med and Dental Sci. 2014; 3(35), August 14; 9272-8.

24. Bandekar PK, Kale PB. Placenta in pregnancy induced hypertension. Int $\mathbf{J}$ Reprod Contracept Obstet Gynecol. 2018;7:467-9.

25. Londhe PS \& Mane AB. Morphometric study of placenta and its correlation in normal and hypertensive pregnancies. International Journal of Pharma and Biosciences. 2011; 4(2): 429-437.

26. Modi H N, Umaraniya YN, Prajapati HK, Rathod JB, Chauhan HM \& Chaudhary SM . Morphology of placenta in pregnancy induced hypertension. Medical sciences. 2013; 2(9), 273-274.

27. Salmani D, Purushothaman S, Chikkannashetty S, Somashekara, Gnanagurudasan E \& Sumangaladevi K. Study of structural chanhes in placenta in pregnancy induced hypertension. Journal of natural science, Biology and medicine.2014; 25(2), 352-355

28. Devishankar K, Bhanu PS, Kiran S, Ramakrishna BA \&Shanthi V. Vasculo syncytial membrane in relation to syncytial knots complicates the placenta in preeclampsia: A histomorphometrical study. Anat Cell Biol. 2012; 45: 86-91.

29. Karmakar MK, Kar S, Kumar SM, Chattopadhyay SK, Vaid LK, Sen S. A study of histological changes of human placenta in rural population of eastern 


\section{PLACENTAS CHANGES IN GESTATIONAL HYPERTENSIVE WOMEN}

India. Int J Reprod Contracept Obstet Gynecol. 2018;7:3280-7.

30. Al-Mamori RHL. Macroscopical and microscopical study of placenta in normal and pregnancy induced hypertension. Al-Qadisiah Med J.2010; 6(10): 18-26.

31. Kurdukar MD, Deshpande NM, Shete SS \&Zawar MP. Placenta in PIH. Indian J Pathol Microbiol. 2007; 50 (3): 493-497.

32. Dadhich A , Kataria SK, Kataria KR \&Potaliya P. Study of effect of eclampsia and chronic hypertension on gross morphology of placenta. J Biol Med Res.2012; 3(2): 1771-1773

33. Fox H. Abnormalities of the foetal stem arteries in the human placenta. Journal of Obstetrics and Gynaecology of British Common wealth. 1967; 74: 734-738

34. Agarwal G C, SainiP, Pankaj J P, Pandey L N, Jain A. Morphological study of placenta in normal and hypertensive pregnancies. IAIM. 2015; 2(5): 121-128.
35. Dhawle MS, Tangde AR, Mundhe BP, Rathod SG, Bindu RS. Morphological study of placenta in pregnancy induced hypertension. Int J Res Med Sci. 2017; 5:3214-7.

36. KristinaL, Raanan S \&Reecca B. Syncytial knots as a reflection of placental maturity: reference values for 20 to 40 weeks gestational age. Pediatric and developmental pathology.2010; 13(4):305-9.

37. Navbir P, Alka N \& Antima G. Histological changes in placentae in pregnancies complicated by preeclampsia and eclampsia and correlation with fetal outcome. Int $\mathbf{J}$ Pharm Bio Sci. 2012; 3(2): 551-60.

38. Mehendale SS, Lele V \& Godbole PV. Placental histopathology with intrauterine growth retardation. 1988; 138: 406-9.

39. Kaur P, Sharma S, Harsh \& Kaushal S. Comparison of Villi in Pregnancy Induced Hypertensive and Normotensive Pregnancies. Ann Int Med Den Res. 2017; 3(4):10-12. 


\section{يوخته}

كور انكارييت مالبيجكيى لداف ئافرهتيّن ئهويّن فثثار خوينيّن بلند يا دووكيانيّن هلين ل دهوكيّ

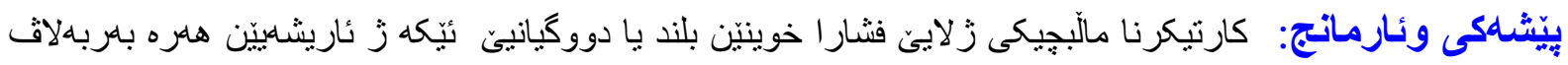

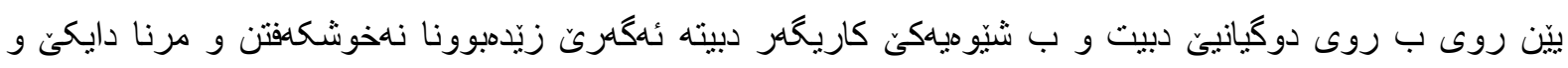

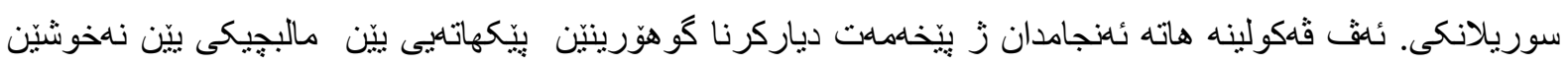

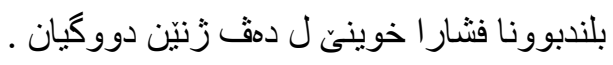

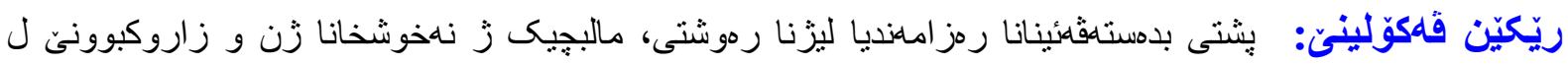

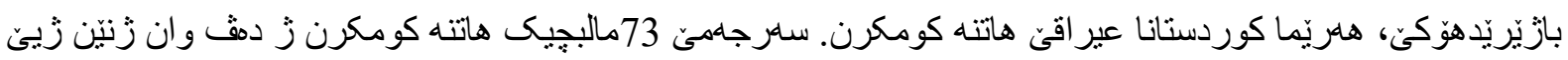

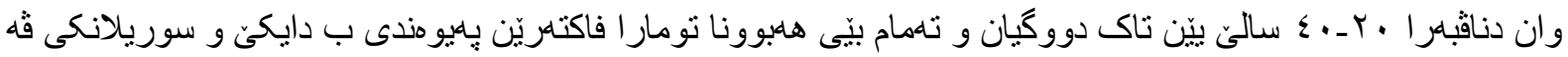

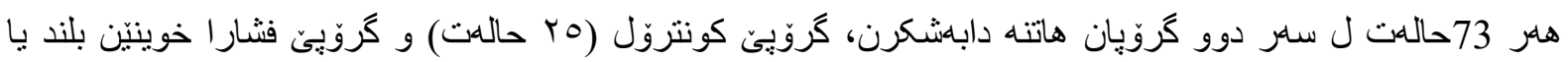

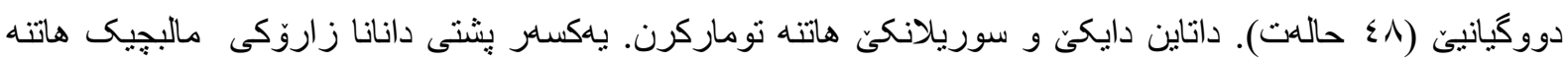

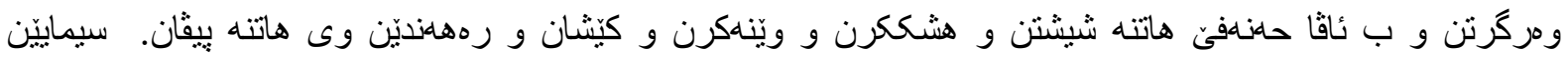

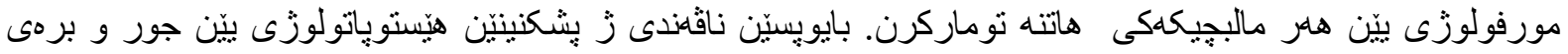

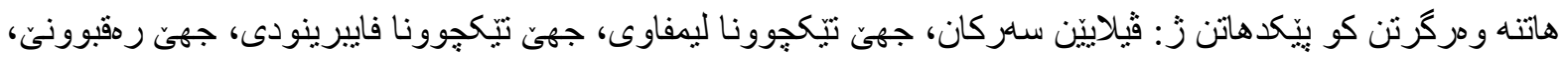

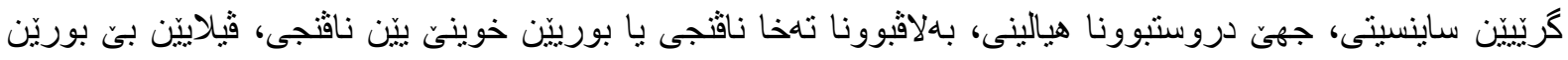

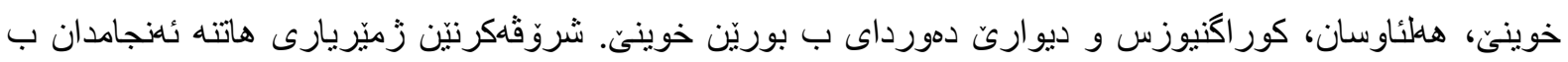
يشكنينا ت-تيّست و كاى-سكويّر.

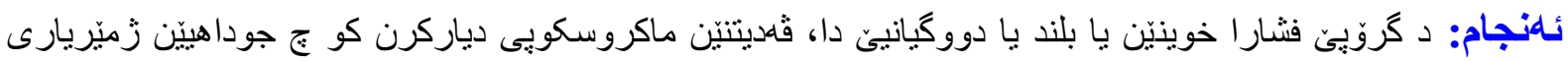

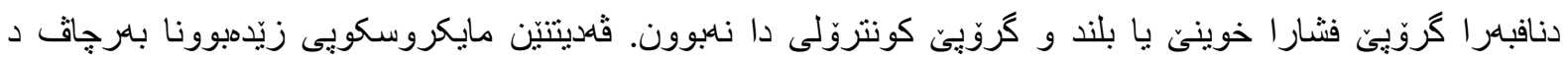

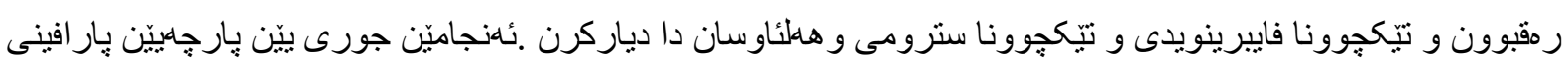

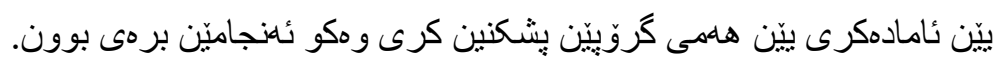

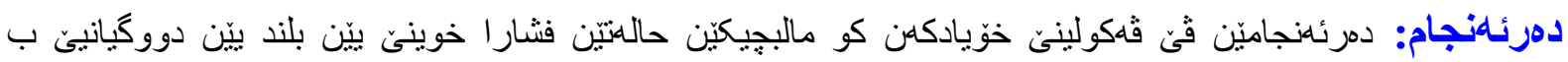

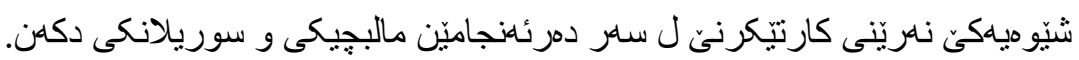




\section{الخلاصة}

\section{تغييرات المشايم في النساء المصابات بفرط ضغط الام الحملي في دهوك}

الخلفية وأهدف البحث: تتأثر المشايم بفرط ضغط الدم الحملي ويسهم بشكل كبير في إمراضية وحدوث الوفيات الأمومية و الجنينية. تم تصميم هذه الدر اسة لبحث التغير ات العيانية لمشايم اضطر اب فرط الضغط.

طرق البحث: تم جمع عينات هذه الدر اسة من مستشفى دهوك لأمر اض التوليد و النسائية في مدينة دهوك. إقليم كوردستان العر اق. لقد تم جمع 73 مشيمة من النساء اللو اتي تتر اوح أعمار هن بين 20-40 سنة ذوات الحمل الكامل المفرد, 25 مشيمة من امهات ضغط الدم السوي لم يصبن سابقا بفرط الضغط كمجمو عة تحكم و 48 مشيمة من نساء

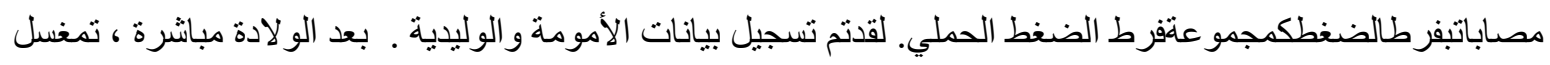

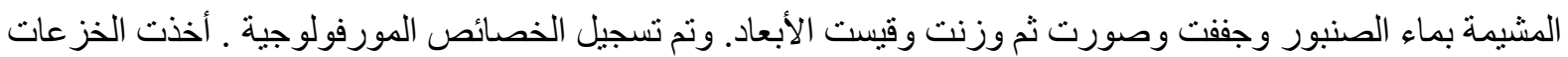
المركزية لفحص النسيج كميا ونوعيا, و الكمي يشمل: الزغابات الطرفية ، منطقة التليف السدوي ، منطقة النخر اللبفانيني ،

منطقة التكلس ، العقد المخلوية ، منطقة التحول الزجاجي ، تكاثثر طبقة الإنسي من الأوعية الدموية المتوسطة الحجم ، الزغابات اللاوعائية ، الاحتقان، زيادة تكون الأوعية الشعرية الدمويةchorangiosis و الغشاء الوعائي المخلوي

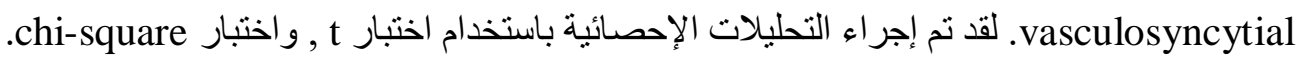

النتائج: في مجموعة فرط ضغط الدم الحملي ، أظهرت النتائج العيانية أنه لا يوجد فرق إحصائي بين مجموعة ارتفاع ضغط الدم ومجموعة التحكم. لقد كثف الفحص المجهري عن حدوث زيادة معنوية في التكلس و النخر الليفانيني ، والتليف السدوى ؛ و الأحتقان ـ في حين أزداد الغشاء الوعائي المخلوي و الزغابات اللاوعائية بشكل غير معنوي ولم يتأثر تكون الأو عية الثعرية الدموية. في مجمو عقفرطضغط الدم الحملي ، نطابقت النتائج النو عية العيانية و النسيجية مع النتائج الكمية.

الأستنتاجات: تتأثر المشايم بشكل معنوي و عكسي بفرط ضغط الدم الحملي. 